\title{
Mathematical Modeling of Gas-Cleaning Equipment with a Highly Developed Phase Contact Surface
}

\author{
Plyatsuk L. D. ${ }^{1}$, Ablieieva I. Yu. ${ }^{1}$, Vaskin R. A. ${ }^{1 *}$, Yeskendirov M. ${ }^{2}$, Hurets L. L. ${ }^{1}$ \\ ${ }^{1}$ Sumy State University, 2 Rymskogo-Korsakova St., 40007 Sumy, Ukraine; \\ ${ }^{2}$ M. Auezov South Kazakhstan State University, 5 Tauke Khan Avenue, 160012, Shymkent, Republic of Kazakhstan
}

Article info:

Paper received:

The final version of the paper received:

Paper accepted online:
*Corresponding Author's Address:

r.vaskin@gmail.com
July 5, 2018

October 30, 2018

November 4, 2018

\begin{abstract}
The deposition of aerosols from process gas streams are the basis of many technologies in the chemical, petrochemical, coke, oil, gas, food etc. Industrial gases, containing aerosols of different nature of origin polydisperse solid particles (dust, smoke) or liquid particles (fog), must be cleaned. The idea of the author is to develop a mathematical model of the process of trapping waste gases, fogs in intensive nozzles with a developed surface of contact of phases. The vortex flow of the gas-liquid flow and its pulsating nature of the movement contribute to the intensification of the crushing process and coagulation of the drop gas-liquid flow in the layer of a regular moving nozzle. Methods of mathematical modeling of the process of movement of a polydisperse aerosol in a turbulent gas-liquid flow have been used. It was determined that condensation of steam in the cell occurs on the surface of the nozzle and also the formation of new germs of aerosol particles. The size distribution of aerosol particles is due to centrifugal forces. In this case, large particles are removed from the vortex region into a continuous flow, while small particles rotate in a vortex. Coagulation equation describing the change in the particle size distribution function with time, undergoing condensation and coagulation growth. The obtained results of differential and integral-differential equations can be used to describe the formation process and aerosols. Environmental and economic efficiency, as well as the optimal choice of environmental and auxiliary equipment took into account.
\end{abstract}

Keywords: "wet" cleaning technologies, regular moving nozzle, polydisperse aerosol, gas-liquid flow, condensationcoagulation integration.

\section{Introduction}

The activities of the chemical and petrochemical industries are accompanied by the formation and release of a wide range of pollutants into the air. The deposition of aerosols from process gas streams are the basis of many technologies in the chemical, petrochemical, coke, oil, gas, food etc. At the same time, they rather often resort not to preventive methods, but to "pipe" methods in order to achieve environmental safety standards (MPC) and technological (MPE) standards. So in the production of various formed products industrial gases containing aerosols of different nature of origin is a polydisperse solid particles (dust, smoke) or liquid particles (fog), from which the gases have to be cleaned [1].

In order to reduce the concentration of pollutants, technologies of "wet" and "dry" cleaning are used, implemented with the help of various hardware design.
The process of trapping occurs in mass transfer equipment at the end of the process. Purified dust and gas flow after exiting the cleaning equipment is released into the atmosphere and moves in the direction of the steady movement of air masses, i.e. on the wind rose, besieging at the same time.

From the point of view of environmental, economic and technological aspects, the process of "wet" cleaning of flue gases from aerosols (fumes, dust, fogs, etc.) is more efficient. Such mass exchangers include apparatuses with a nozzle, a regular nozzle, a shelf nozzle, which have a high degree of purification (trapping).

One of the main approaches to the design and development of cleaning devices is associated with the principle of heuristic modeling, which allows a number of optimization calculations to be performed under various initial conditions. 


\section{Literature Review}

When a system-located contact elements flow around a gas-liquid flow in their root part, periodic formation and disruption of vortices occur, which form a vortex "path" of the pocket behind the streamlined contact element [2]. Depending on the shape of the cross section of the contact element, their location in the contact zone may be in a horizontal and vertical position. There may also be a case of mine location of the vortices, which predetermines the formation of a vortex wake.

The movement of the gas-liquid flow after a streamlined contact element occurs in a pulsating mode, inherent in the separated flow. The vortex flow of the gasliquid flow and its pulsating nature of the movement contribute to the intensification of the crushing process and coagulation of the drop gas-liquid flow in the layer of a regular moving nozzle.

The results obtained in the work [3] confirm the theoretical ideas about the mechanism and regularities of the deposition of small fractions, for which the thickness of the boundary layer significantly affects the approach of particles to the deposition surface.

The study of the inadequate influence of the mechanisms of turbulent and inertial deposition allowed the researchers [1] to make a statement about the inappropriateness of increasing the velocity of the gas more than 15 $\mathrm{m} / \mathrm{s}$ when trapping mist particles with a disparity $\mathrm{dr}<0.6$ microns.

Authors of the article [4] analyzed the process of coagulation of aerosol particles in turbulent aerosol flows as they flow through a layer of regularly placed turbulizing cylindrical elements (diameter $d_{c}$ ) installed in a planeparallel channel (with a step $t_{b}$ ). Those, in the streams, where the in-phase vortex formation mode was implemented, which predetermined the extreme values of the hydrodynamic and heat and mass transfer characteristics of the flow. It is determined that when the concentration of steam exceeds $30 \mathrm{mg} / \mathrm{m}^{3}$, the growth efficiency of particle sizes drops significantly.

Virtually all particles supplied by turbulent gas pulsations to the boundary of the laminar sublayer are deposited on the surface of the channel walls. The proximity of the dispersed composition of the initial and final aerosols [5] indicates the predominant role of diffusive sedimentation of particles. The aerosol particles, which are supplied by turbulent gas pulsations to the interface, have significant inertia and, as a result, can penetrate into the boundary layer.

In the contact zone, the principle of longitudinal partitioning is implemented using various nozzle designs. The most effective is a regular mobile nozzle. The turbulizing nozzle allows a high degree of purification from fogs, aerosols and polydisperse gas and liquid streams.

The nature and intensity of movement of the main carrier gas-liquid flow in direct-flow interaction of the phases determines the hydrodynamics of the gas cleaning apparatus.

In the article [6] are derived equations for calculating the thickness of the descending liquid film, starting from the balance of forces acting on the liquid film formed on the elements of the regular nozzle during the direct-flow mode of phases (both upward and downward), as well as the resistance of a plate-shaped cap coated with a film. However, these mathematical models and algorithms for calculating devices with a regular moving nozzle do not take into account the polydisperse composition of the droplet component of the surface of the contact phase.

To solve equations of the mathematical model related to the removal efficiency of a Venturi scrubber scientists [7] used an upwind control-volume method. This method is applicable to convection and diffusion equations when the Peclet number is greater than 2. For high Peclet numbers, the common numerical error of false diffusion can be neglected and, in spite of the simplicity of the upwind scheme, the numerical results are valid.

Authors of the article [8] made an attempt for application of the system-element approach in building a physical and mathematical model of a chemical process to create an ecologically safe equipment. However, the paper presents only the structure and algorithm of the mathematical description of the coagulation processes (including condensationcoagulation integration) and the deposition of aerosols, without mathematical models.

The aim of the work is to develop a mathematical model of the process of trapping waste gases, fogs in intensive nozzles with a developed surface of contact of phases.

\section{Research Methodology}

Consider the process of movement of a polydisperse aerosol in a turbulent gas-liquid flow. The enlargement of the aerosol is due to the condensation mechanism. Condensation of steam in the cell occurs on the surface of the nozzle and also the formation of new germs of aerosol particles.

The total balance for the pair can be written as:

$$
Q_{s}^{(f)}=Q_{s}^{(i n)}-\sum_{i=1}^{n} Q_{i}
$$

where $Q_{s}^{(i n)}$ is the initial quantity of steam, $\mathrm{J} ; Q_{s}^{(f)}$ is the final quantity of steam, $\mathrm{J}$; the sum is the amount of steam going to condensation, $\mathrm{J}$ :

$$
\sum_{i=1}^{n} Q_{i}=Q_{1}=Q_{2}+Q_{3}
$$

where $Q_{1}$ is the amount of steam condensing on the nozzle, $\mathrm{J} ; Q_{2}$ is the amount of steam condensing on the surface of the aerosol, $\mathrm{J} ; Q_{3}$ is amount of condensed steam, $\mathrm{J}$.

To determine the condensed steam on the surface of the nozzle elements, we use the mass transfer equation:

$$
\frac{d Q_{1}}{d t}=\frac{\beta_{s} F}{R_{g} T_{s g}}\left(P_{s}-P_{w}\right)
$$

where $Q_{1}$ is the amount of steam condensing on the nozzle, $\mathrm{J} ; t$ is time, sec; $\beta_{s}$ is steam mass transfer coefficient; $F$ is the surface of the contact phase (condensation), $\mathrm{m}^{2} ; P_{s}$ is steam partial pressure, $\mathrm{Pa} ; P_{w}$ is steam partial pressure at the 
wall, $\mathrm{Pa} ; R_{g}$ is universal gas constant; $T_{s g}$ is steam gas mixture temperature, $\mathrm{K}$.

The amount of condensed steam on the particles is determined using the dependencies:

$$
\frac{d Q_{2}}{d t}=N_{r} \int_{0}^{\infty} \frac{d Q_{r}}{d t} f(r, t) d r
$$

where $\mathrm{d} Q_{2} / \mathrm{d} t$ is the amount of steam condensing on a single particle; $N_{r}$ is the total number of particles involved in the condensation process; $f(r, t)$ is distribution function of aerosol particles in size.

The initial distribution function of aerosol particle size is subject to the normal-logarithmic distribution [9], in the initial period of condensation:

$$
f=(r, 0)=\frac{1}{r \ln \sigma \sqrt{2 n}} \exp \left[-\frac{(\ln r-\ln \bar{r})^{2}}{2 \ln ^{2} \sigma}\right]
$$

where $\bar{r}$ is the average geometric radius of particles, $\mathrm{m} ; \sigma-$ standard deviation.

The change in mass of a single particle [10] is determined by

$$
\frac{d Q_{r}}{d t}=\frac{4 \pi \beta_{s} M_{s} r}{R_{g} T_{s g} \varphi}\left[P_{s}-\rho_{g}\left(T_{g}\right)\right]
$$

where $M_{\mathrm{s}}$ is the molecular mass of steam, $\mathrm{kg} / \mathrm{kmol} ; \rho_{\mathrm{g}}$ is gas density, $\mathrm{kg} / \mathrm{m}^{3}$.

In this equation the Knudsen number $K_{n}$ is introduced for determining the following parameter:

$$
\varphi=1+\frac{1,33 K_{n}+0,71}{1+K_{n}}
$$

To change the radius of particles in time, we convert equation (6) into formula (7):

$$
\frac{d r}{d t}=\frac{3 \beta_{s} M_{s}}{r R_{g} T \varphi \varphi_{g}}\left[P_{s}-\mathrm{P}_{g}(T)_{g}\right]
$$

The temperature and pressure of the steam-gas mixture will be determined based on the mixing balance:

$$
\begin{gathered}
T=\frac{T_{g}+a b T_{s}}{1+a b} \\
P=\frac{P_{g}+a c P_{s}}{1+a c}
\end{gathered}
$$

where $a=Q_{s} / Q_{g}, b=C_{s} / C_{g}, C=M_{s} / M_{g}$, and $C_{s}, C_{g}$ are the heat capacities of steam and gas, respectively, $\mathrm{J} /(\mathrm{kg} \cdot \mathrm{K})$.

\section{Results and Discussion}

The solution of equation (7) together with equations (8) and (9) has a physical meaning in the case of a uniform distribution of temperature and pressure in the volume of the conventional cell, with a laminar flow of the gas-steam mixture. In the case under study, the gas-liquid (steam-gas) mixture is in an intense turbulent mode, which causes pressure drops (fluctuation), flow temperatures over the cross section and in the volume of the contact zone.

Considering the flow in a single vortex and based on the principles of theoretical hydrodynamics [4], we assume that the vortex consists of a nucleus rotating according to the law of a solid body and a vortex field (Fig. 1).

To change the linear velocity of motion from the radius of the vortex, we can write:

1) for the vortex core $\left(R_{\mathrm{i}}<R\right)$ :

$$
\int_{s} U_{i} d S^{(Q)}=\omega \pi R_{i}^{2}
$$

2) for the vortex field $\left(R_{b}>R\right)$ :

$$
\int_{s} U d S^{(Q)}=\omega \pi R^{3}
$$

where $S$ is sectional area of the vortex, $\mathrm{m}^{2} ; \omega$ is angular velocity, $\mathrm{s}^{-1} ; U, U_{i}$ - constants on the corresponding vortex circles.

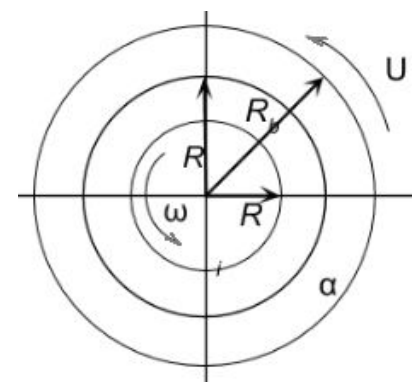

Figure 1 - Scheme of vortex motion

For the vortex core we write the equations

$$
2 \pi R_{i} U_{i}=\omega \pi R_{i}^{2}
$$

for the vortex field

$$
2 \pi R_{B} U=\omega \pi R^{2}
$$

Then for the vortex core we get

$$
U_{i}=\frac{\omega R_{1}}{2}
$$

for the vortex field

$$
U=\frac{\omega R}{2 R_{2}}
$$

Substituting in equations (14), (15) the value of the angular velocity equal to

$$
\omega=I / \pi R^{2}
$$

where $I=U_{c}^{2} /(2 f)=U_{g} d_{c} /(2 S l)$ is the intensity of the circulation rate, $\mathrm{m}^{2} / \mathrm{s} ; f$-vortex breakdown frequency, $\mathrm{s}^{-1} ; \mathrm{Sl}-$ Strouhal number. 
Will get

$$
\begin{aligned}
& U_{i}=\frac{I R_{i}}{2 \pi R^{2}} \\
& U=\frac{I}{2 \pi R_{B}}
\end{aligned}
$$

Knowing the laws of variation of the linear flow velocity along the vortex radius, we determine the pressure drop in the core and the vortex field.

The law of conservation of momentum in cylindrical coordinates can be written in the form:

$$
\rho \frac{U}{R}=\frac{\partial P}{\partial R}
$$

Substituting in the equation (19) the value of the linear velocity from equations (17), (18) and integrating over pressure from $P_{0}$ to $P$, as well as along the vortex radius from 0 to $R$, we get

$$
P=\frac{I^{2} R^{2} \rho_{g}}{8 \pi^{2} R_{B}^{4}}+P_{0}
$$

where $P_{0}$ is the pressure in the center of the vortex, $\mathrm{Pa}$; $P$ is gas pressure, $\mathrm{Pa}$.

Then for the field of the vortex dependence will be:

$$
P_{R}=P_{g}-\frac{I^{2} \rho_{\Gamma}}{8 \pi^{2} R^{2}}
$$

for $P_{0}$, we can write the expression

$$
P_{0}=P_{g}-\frac{I^{2} \rho_{g}}{4 \pi^{2} R_{B}^{2}}
$$

and for the vortex we write the following relation

$$
P_{R^{*}}=P_{g}-\frac{I^{2} \rho_{g}}{4 \pi^{2} R_{B}^{2}}\left(1-\frac{R_{*}^{2}}{2 R_{B}^{2}}\right)
$$

Finally, for a steam-gas flow around a nozzle element with a geometric dimension $d_{c}$, the pressure drop in a single vortex will be written:

1) for the vortex core

$$
P_{R^{*}}=P_{g}-\rho_{g}\left(\frac{U_{c} d_{c}}{4 \pi R_{b} S l}\right)^{2}\left(1-\frac{R_{*}^{2}}{2 R_{B}^{2}}\right)
$$

2) for the vortex field

$$
P_{R}=P_{g}-\frac{\rho_{g}}{8}\left(\frac{U_{g} d_{c}}{4 \pi R_{6} S l}\right)^{2}
$$

In the case of an adiabatic steam - gas mixture, a similar solution together with the adiabatic equation allows one to obtain pressure drops:

$$
\begin{gathered}
\Delta P_{R^{*}}=\frac{k-1}{k} \rho_{g}\left(\frac{U_{c} d_{c}}{4 \pi R_{b} S l}\right)^{2}\left(1-\frac{R_{*}^{2}}{2 R_{B}^{2}}\right) \\
\Delta P_{R}=\frac{k-1}{k} \frac{\rho_{g}}{8}\left(\frac{U_{g} d_{c}}{4 \pi R_{g} S l}\right)^{2}
\end{gathered}
$$

where $k$ is the adiabatic index.

To obtain the dependences on the temperature variation of the steam-gas mixture in a single vortex when solving equations (26) and (27) together with the equation of state of an ideal gas $P \cdot V=R \cdot T$, we obtain for the core

$$
\left.\Delta T_{R^{*}}=\frac{k-1}{k} \frac{1}{R_{\mathrm{g}}}\left(\frac{U_{g} d_{c}}{4 \pi R S l}\right)^{2} \int_{\alpha} 1-\frac{R_{*}^{2}}{2 R^{2}}\right)
$$

for the field

$$
\Delta T_{R}=\frac{k-1}{k} \frac{1}{2 R_{\mathrm{g}}}\left(\frac{U_{\mathrm{g}} d_{c}}{4 \pi R S}\right)^{2}
$$

In equations (26) - (29) the size of the radius $R_{B}$ and vortex core $R_{*}$ can be determined by the formulas:

$$
\begin{gathered}
R_{B}=0,25 d_{c} \\
R_{*}=\left(5,04 v_{g} t\right)^{1 / 2}
\end{gathered}
$$

where $t_{B}$ is the formation time of the vortex, $\mathrm{s} ; v_{g}$ is the coefficient of kinematic viscosity, $\mathrm{m}^{2} / \mathrm{s}$.

The formation of each vortex, breaking with the nozzle element and its formation time is equal to:

$$
t_{B}=0,5 d_{c} / U_{B}
$$

where $U_{B}=0.86 U_{g}$ is the speed of the vortex, $\mathrm{m} / \mathrm{s}$.

The size distribution of aerosol particles is due to centrifugal forces. In this case, large particles are removed from the vortex region into a continuous flow, while small particles rotate in a vortex.

Using a number of assumptions, we will calculate the structure of a two-phase flow with the determination of the trajectory of the particles inside the vortex, the critical radius of aerosol particles, and the time of formation of the vortex.

To describe the process of movement of particles, apply the equation

$$
\frac{d^{2} x}{d t^{2}}+\frac{1}{A} \frac{d x}{d t}-\frac{1}{x^{3}}=0
$$

where $x=R / R_{B} ; t=t_{c} \cdot U_{p t} / R_{h}$ is the dimensionless quantity; $U_{p t}$ is tangential velocity of the particle, $\mathrm{m} / \mathrm{s}$. The parameter $A$ can be evaluated by the following formula:

$$
A=\frac{r_{p}\left(\rho_{p}-\rho_{g}\right) U_{p t}}{72 \mu_{g} R}
$$


Equation (33) is a nonlinear differential equation; it has no analytical solution. If we neglect the second-order differential, divide the variables and integrate $\mathrm{t}$ from 0 to $\mathrm{t}$ and $\mathrm{x}$ from $\mathrm{x}_{1}$ to $\mathrm{x}_{2}$, and substitute the values $U_{p t}=U_{g}$ from equation (17), then we can determine the critical particle radius for the vortex core:

$$
r_{c r}=4,08 S l\left(\frac{\mu_{g}}{\rho_{p}-\rho_{g}}\right)^{1 / 2}\left(\frac{d y}{U_{g}}\right)^{1 / 2}
$$

The process of coagulation of aerosol particles in the cell volume is not the only one in volume. The presence of turbulent pulsations and Brownian motion of particles leads to growth. Given these conditions, the coagulation equation describing the change in the particle size distribution function with time, undergoing condensation and coagulation growth

$$
\begin{aligned}
& \frac{\partial f\left(r_{p}, t\right)}{\partial t}+\frac{\partial}{\partial r}\left[f\left(r_{p}, t\right) \frac{d r}{d t}\right]= \\
& =\int_{r=0}^{r=r_{p} / \sqrt[3]{2}} K_{C} \sqrt[3]{r_{a v}^{3}-r^{3}, r} \times \\
& \times f\left(\sqrt[3]{r_{p}^{3}-r^{3}}, t\right) f(r, \tau)\left(\frac{r}{\sqrt[3]{r_{p}^{3}-r^{3}}}\right)^{2} d r- \\
& -\int_{r=0}^{r=\infty} K_{C}\left(r_{p}, t\right) f\left(r_{p}, t\right) f(r, t) d r+ \\
& +\frac{Q}{V_{c}}[f(r, 0)-f(r, t)]
\end{aligned}
$$

where $r$ is the current radius of the aerosol particle, $\mathrm{m}$; $Q$ is aerosol consumption, $\mathrm{m}^{3} / \mathrm{s} ; V c$ is cell volume, $\mathrm{m}^{3}$; $K_{C}$ is coagulation coefficient due to turbulent and Brownian mechanisms, $\mathrm{m}^{3} / \mathrm{s}$.

The coagulation coefficient $K_{C}$ is calculated as the sum of the coefficients by turbulent $K_{T}$ and Brownian coagulation $K_{B}$

$$
\begin{aligned}
& K_{C}=K_{T}+K_{B} \\
& K_{B}=\frac{4 k_{b} T_{g}}{3 \mu_{g}},
\end{aligned}
$$

where $k_{b}$ is the Boltzmann constant.

The coefficient of turbulent coagulation [8] is determined by:

$$
K_{T}=1,67\left(r_{p}+r\right)^{3} \sqrt{E / v_{g}}
$$

The energy dissipation $E$ in the volume of the cell $E$ is defined as:

$$
E=\frac{N_{B}}{V_{c} \rho_{s g}}
$$

Here $N_{B}$ is the power of the vortex formed when a nozzle flows around a continuous flow.

The vortex power is determined by the equation:

$$
N_{B}=C_{L} \sqrt{\frac{C_{L}}{C_{D}}} \rho_{s g} l_{c} d y \frac{U_{g}^{3}}{2}
$$

where $C_{L}$ is the lift coefficient; $C_{D}$ is coefficient of resistance; $U_{g}$ is true gas flow rate, $\mathrm{m} / \mathrm{s} ; l_{c}$ is geometrical size of the nozzle, $\mathrm{m}$.

Cell volume is:

$$
V_{c}=b \cdot I_{c} \cdot t_{b . c}
$$

where $b$ is the width of the plane-parallel channel, $\mathrm{m} ; t_{b . c}$ is cell height equal to the center distance between the elements of the nozzle, $\mathrm{m}$.

Substituting the expressions (40) and (41) into equation (39) we get

$$
E=\frac{C_{L D}}{2 b} \frac{d y}{t_{b}} U_{g}^{3},
$$

where

$$
C_{L D}=C_{L} \sqrt{\frac{C_{L}}{C_{D}}}
$$

The developed models make it most likely to establish the mechanism of interaction of dispersed particles with a continuous flow, taking into account the structural features of the developed apparatus.

\section{Conclusions}

On the basis of the conducted substantiation and calculations, it is possible to obtain a system of differential and integral-differential equations, which make it possible to describe the formation process and aerosols due to condensation and coagulation growth. In this way, it becomes possible to carry out the calculation of the effective capture of waste gases, fogs in intensive packing devices with a developed surface of the contact of phases.

The design and performance parameters of the developed apparatus were calculated to determine the environmental and economic efficiency, as well as the optimal choice of environmental and auxiliary equipment, without which the assembly of the unit, installation and production line is impossible. 


\title{
References
}

1. Yeskendirov, M. Z., Sadyrbaev, A. S., Turebekova, A. M., \& Vozzhaeva, N. S. (2017). Studies of trapping of aerosols in turbulent two-phase flows. Retrieved from https://www.eduherald.ru/pdf/2017/3/17215.pdf.

2. Kafarov, V. V., \& Dorokhov, I. N. (1976). System analysis of chemical technology processes. Science, Moscow, Russia.

3. Sabyrkhanov, D. S. (1996). Development, calculation and implementation of mass transfer and dust collecting devices with a movable and regular packing. Shymkent.

4. Sadyrbaeva, A. S., Eskendirov, M. Z., Usipbaev, U. A., Asylbek, N. U., \& Asylbek, G. U. (2017). Studies of the integration of aerosol particles in turbulent two-phase flows. International Student Science Journal, Vol. 5. Retrieved from http://www.eduherald.ru/ru/article/view?id=17314.

5. Golubev, V. G., \& Brener, A. M. (2002). Features of film condensation from a dusty steam-gas mixture. Theoretical foundations of chemical technology, Vol. 36, Issue 2, pp. 141-146.

6. Sadyrbayeva, A. S., Eskendirov, M. Z., Ussipbayev, U. A., et al. (2017). Investigation of the hydrodynamic characteristics of the liquid film flow. Bulletin of the Eurasian National University named after L. N. Gumilyov, Vol. 4 (119), pp. $175-177$.

7. Talaie, M. R., Fathikalajahi, J., \& Taheri, M. (1997). Mathematical modeling of $\mathrm{SO}_{2}$ absorption in a Venturi scrubber. Journal of the Air and Waste Management Association, Vol. 47 (11), pp. 1211-1215, doi: 10.1080/10473289.1997.10464066.

8. Altukhov, A. V., Balabekov, O. S., Volnenko, A. A., \& Balabekov, M. O. (2013). Methodology for the study and calculation of an environmentally perfect unit. Scientific research and their practical application. Modern state and ways of development.

9. Dzyubenko, B. F., Kuzma-Kichta, Yu. A., Holpanov, L. P., et al. (2008). Intensification of heat and mass transfer at the macro, micro and nano scales. TSNIIATOMINFORM, Moscow, Russia.

10. Sadyrbaeva, A. S., Yeskendirov, M. Z., Usipbaev, U. A., Sadyrbaeva, A. S., Ormanova, G. M., \& Asylbek, N. U. (2017). Turbulent-diffusion mechanism for aerosol deposition in the presence of a water steam concentration gradient. Bulletin of the Eurasian National University named after L. N. Gumilyov, Vol. 4 (119), pp. 178-182.

\section{Математичне моделювання газоочисного обладнання} з високорозвиненою поверхнею контакту фаз

\author{
Пляцук Л. Д. ${ }^{1}$, Аблєєва І. Ю. ${ }^{1}$, Васькін Р. А. ${ }^{1}$, Сскендіров М. ${ }^{2}$, Гурець Л. Л. ${ }^{1}$ \\ ${ }^{1}$ Сумський державний університет, вул. Римського-Корсакова, 40007, м. Суми, Україна; \\ 2 Південно-Казахський національний університет ім. М. Ауезова, \\ просп. Тауке Хан, 5, 160012, м. Шимкент, Республіка Казахстан
}

\begin{abstract}
Анотація. Осадження аерозолів 3 технологічних газових потоків лежить в основі багатьох технологій хімічної, нафтохімічної, коксохімічної, нафто-газової, харчової промисловості тощо. Промислові гази, що містять аерозолі різної природи походження, полідісперсні тверді частинки (пил, дим), або рідкі частинки (туман) необхідно очищувати. Авторська ідея полягає у розробленні математичної моделі процесу захоплення відхідних газів, туманів в інтенсивних насадках з розвиненою поверхнею контакту фаз. Вихровий газо-рідинний потік та пульсуючий характер його руху сприяють інтенсифікації процесу дроблення i коагуляції при падінні газорідинного потоку в шарі традиційної рухомої насадки. Використовуються методи математичного моделювання процесу руху полідисперсного аерозолю в турбулентному газорідинному потоці. Встановлено, що конденсація пари у комірці відбувається на поверхні насадки, а також утворюються нові зародження частинок аерозолю. Розподіл частинок аерозолю відбувається завдяки відцентровим силам. У цьому випадку відносно великі частинки видаляються з вихрової області до безперервного потоку, а невеликі частинки обертаються у вихорі. Рівняння коагуляції, що описує зміну функції розподілу за розміром частинок з часом, ураховує конденсацію і зростання коагуляції. Отримані результати диференціальних та інтегро-диференціальних рівнянь можуть бути використані для описання процесу формування аерозолів. Ураховано екологічну та економічну ефективність, а також оптимальний вибір екологічного та допоміжного обладнання.
\end{abstract}

Ключові слова: технології «мокрого» очищення, насадка з регулярним переміщенням, полідисперсний аерозоль, газорідинний потік, конденсатно-коагуляційна інтеграція. 